\title{
HUBUNGAN ANTARA KECERDASAN SOSIAL DAN GAYA KEPEMIMPINAN DEWAN EKSEKUTIF MAHASISWA (DEMA) DI IAIN PAREPARE TAHUN 2018
}

\author{
Mardiana \\ Bimbingan Konseling Islam \\ IAIN Parepare
}

\section{PENDAHULUAN}

Manusia merupakan salah satu bagian dalam organisasi yang amat penting sebagai salah satu faktor dan pendukung organisasi. Perilaku organisasi hakikatnya adalah hasil-hasil interaksi antara individu-individu dalam organisasinya. Oleh karena itu, untuk memahami perilaku organisasi sebaiknya diketahui terlebih dahulu individu-individu sebagai pendukung organisasi tersebut ${ }^{1}$. Organisasi yang dibentuk memiliki tujuan dan adapun hal yang dibatasi sebagai suatu konsep akhir yang diinginkan atau kondisi yang dapat dijadikan usaha melalui penampilan aktivitas dalam tugas-tugas mereka.

Adapun fungsi organisasi diantaranya adalah memenuhi kebutuhan pokok organisasi, mengembangkan tugas dan tanggung jawab sesuai dengan program kerja yang telah disusun sebelumnya pada Musyawarah Besar (MUBES) yang dilaksanakan setiap selesai masa kepengurusan. Dewan Eksekutif Mahasiswa (DEMA) merupakan sebuah organisasi kemahasiswaan formal di tingkat perguruan tinggi. Dewan Mahasiswa berperan sebagai penanganan semua organisasi internal yang berada diruang lingkup kampus dimana hal yang dapat dilakukan sebagai wadah dari penyampai aspirasi mahasiswa, membela hak-hak mahasiswa jika terjadi ketidakadilan yang dirasa merugikan posisi mahasiswa, dan membantu kelancaran kegiatan akademik di kampus.

\footnotetext{
${ }^{1}$ MiftahThoha, PerilakuOrganisasi, (Jakarta: Raja GrafindoPersada,), Cet: 22, h. 33
} 
Organisasi kemahasiswaan ini keanggotaannya mencakup seluruh Mahasiswa Institut Agama Islam Negeri yang terdiri dari berbagai fakultas, angkatan yang berbeda-beda, dan berasal dari Utusan masing-masing organisasi internal yang berada di ruang lingkup kampus itu sendiri.Keseharian para eksekutif mahasiswa ini yang biasanya dikatakan dengan Mentri dalam kampus selalu berada di daerah kampus dan tidak melupakan pula kewajiban mereka sebagai penyampai inspirasi dari apa yang mahasiswa keluhkan dalam hal ini permasalahan yang nantinya tidak berdampak dengan hanya satu orang saja dan disitulah mereka sendiri melatih diri mereka sendiri untuk melakukan kegiatan komunikasi, sehingga komunikasi yang efektif menjadi faktor yang penting bagi pencapaian tujuan suatu organisasi.

Perilaku organisasi adalah suatu studi yang menyangkut aspek-aspek tingkah laku manusia dalam suatu organisasi atau suatu kelompok tertentu. Ia meliputi aspek yang ditimbulkan dari pengaruh organisasi terhadap manusia dengan demikian pula aspek yang ditimbulkan dari pengaruh manusia terhadap organisasi. Tujuan praktis dari penelaahan studi ini adalah untuk mendeterminasi bagaimanakah perilaku manusia itu mempengaruhi usaha pencapaian tujuan-tujuan organisasi. ${ }^{2}$ Allah SWT telah memberi tahu kepada manusia, tentang pentingnya kepemimpinan dalam islam, sebagaimana dalam Al-Quran kita menemukan banyak ayat yang berkaitan dengan masalah kepemimpinan.

Tanggungjawab di sini bukan semata-mata bermakna melaksanakan tugas lalu setelah itu selesai dan tidak menyiksakan dampak (atsar) bagi yang dipimpin. Melainkan lebih dari itu, yang dimaksud tanggungjawab di sini adalah lebih berarti upaya seorang pemimpin untuk mewujudkan kesejahteraan dirinya sendiri. Atau dengan kata lain, seorang mesti bertanggungjawab untuk mencari makan atau menghidupi dirinya sendiri, tanpa mengantungkan hidupnya kepada orang lain.

${ }^{2}$ W. Jack Duncan, organizational Behavior, 1981, H.7 
Hakekat kepemimpinan adalah tanggungjawab dan wujud tanggungjawab adalah kesejahteraan, maka bila orang tua hanya sekedar memberi makan anakanaknya tetapi tidak memenuhi standar gizi serta kebutuhan pendidikannya tidak dipenuhi, maka hal itu masih jauh dari makna tanggungjawab yang sebenarnya. Demikian pula bila seorang majikan memberi gaji prt (pekerja rumah tangga) di bawah standar ump (upah minimum provinsi), maka majikan tersebut belum bisa dikatakan bertanggungjawab. Begitu pula bila seseorang pemimpin, katakanlah presiden, dalam memimpin negerinya hanya sebatas menjadi "pemerintah" saja, namun tidak ada upaya serius untuk rakyatnya dari jurang kemiskinan menuju kesejahteraan, maka presiden tersebut belum bisa dikatakan telah bertanggungjawab. Karena tanggungjawab seorang presiden harus diwujudkan dalam bentuk kebijakan yang berpihak pada konglomerat dan teman-teman dekat. Oleh sebab itu, bila keadaan sebuah bangsa masih jauh dari standar kesejahteraan, maka tanggungjawab pemimpinnya masih perlu dipertanyakan.

Banyak faktor yang mempengaruhi gaya dalam melakukan komunikasi organisasi, salah satunya adalah adanya pemimpin yang memang berpengalaman dalam menjadi seorang yang dapat memimpin organisasi tersebut secara efektif tanpa adannya hal yang dapat memicu terjadinya konflik didalamnya. Perilaku organisasi adalah suatu studi yang menyangkut aspek-aspek tingkah laku manusia dalam suatu organisasi atau suatu kelompok tertentu. Ia meliputi aspek yang ditimbulkan dari pengaruh organisasi terhadap manusia dengan demikian pula aspek yang ditimbulkan dari pengaruh manusia terhadap organisasi. Tujuan praktis dari penelaahan studi ini adalah untuk mendeterminasi bagaimanakah perilaku manusia itu mempengaruhi usaha pencapaian tujuan-tujuan organisasi. ${ }^{3}$ Maka, dalam memilih pemimpin juga diperlukan peninjauan terlebih dahulu mengenai pengalaman dari seorang yang ingin dijadikan seorang pemimpin.

Pemimpin dan para komunikator dalam organisasi perlu memahami dan menyempurnakan kemampuan komunikasi mereka, sehingga dapat terlatih

\footnotetext{
${ }^{3}$ Toto Tasmara, Spiritual Centered Leadership, (Jakarta: Gema Insani Press, 2006), H.5
} 
mengeluarkan argumen yang ada sehingga apabila menghadapi Mahasiswa di luar ataupun orang ternama sekalipun. Menurut Raharja kegagalan berbagai pendekatan tentang kualitas seperti Total Quality Management (TQM) Business Process Reenginering (BPR) dan pendekatan lainnya telah menimbulkan perubahan perspektif dalam memandang kualitas dan dimensi manusia dalam organisasi. Inti penyebab kegagalan pendekatan tersebut terletak pada unsur dimensi manusia, yaitu kurangnya komitmen berbagai pihak (dimensi manusia) yang terlibat dalam organisasi dari berbagai level struktur, fungsi, dan kompetensi dan secara lebih khusus pimpinan organisasi. Dari pernyataan tersebut dapat diketahui bahwa seorang pemimpin mempunyai peranan yang penting dalam keberlanjutan sebuah organisasi atau perusahaan. ${ }^{4}$ Dengan memperhatikan hal tersebut seorang pemimpin dapat menjadikan hal-hal yang diinginkan suatu lembaga dapat terwujud dengan kerjasama yang baik pula.

\section{PEMBAHASAN}

\subsubsection{Teori kecerdasan sosial}

Pandangan para ahli teori kecerdasan sosial untuk hidup bisa dipahami dengan baik dalam konteks sejarah bidang mereka. Pada tahun 1920, ketika Edward Thorndike pertama kali mengusulkan konsep kecerdasan sosial, konsep "IQ" yang baru sedang membentuk pemikiran tentang bidang yang sama barunya, psikometrika, yang bertujuan mencari cara untuk mengukur kemampuan manusia. Pada masa yang sangat menggairahkan itu kesuksesan psikologi dalam memilahmilahkan jutaan pasukan Amerika serikat berdasarkan IQ selama perang dunia II dan dengan begitu, memberikan dasar untuk menugaskan mereka pada tugas dan pos yang bisa mereka tangani secara efektif, membangkitkan kegairahan yang dapat dimengerti.

Ahli-ahli teori awal tentang kecerdasan sosial berusaha untuk mendapatkan suatu analogi IQ yang berlaku pada talenta dalam kehidupan sosial.

\footnotetext{
${ }^{4}$ Raharja, Dimensi Manusia dalam Organisasi: Suatu Kajian Teoritis dari Perspektif Manajemen Kualitas. Jurnal Sosiohumaniora Universitas Padjadjaran, Vol 7, No.1, Maret 2005
} 
Dengan dipandu oleh bidang psikometrika yang baru muncul, mereka mencari cara untuk menaksir perbedaan-perbedaan dalam kemampuan sosial yang akan menjadi padanan dari, katakanlah, perbedaan-perbedaan dalam penalaran spasial dan verbal diukur oleh IQ. ${ }^{5}$ Usaha-usaha awal ini mengecewakan terutama karena kelihatannya upaya-upaya itu mengukur hanya pengertian intelektual orang atas situasi social. Contohnya, satu tes dini atas kecerdasan social mengukur kemampuan kognitif seperti mengidentifikasi situasi social apa yang paling pas untuk sebuah kalimat tertentu.

\subsubsection{Teori system komunikasi}

Teori system komunikasi dalam perspektif Niklas Luhmann. System komunikasi didefenisikan Luhman sebagai interaksi. Sebagai system autopoiesis mereka membentuk diri mereka sendiri dengan operasi berupa komunikasi. System komunikasi memiliki batas-batas, dan masalah referensi pertamanya adalah reduksi kompleksitas. ${ }^{6}$ Luhmann mendefenisikan komunikasi secara eksplisit sebagai kesatuan informasi, pesan dan pemahaman.komunikasi tercipta melalui sintesis dari tiga jenis seleksi perbedaan, yaitu seleksi informasi, seleksi ujaran dari informasinya. (Haramain, 2012, 2016, 2019; Juddah, 2015; Rahmawati, Wahidin and Aris, 2015; Abdullah, 2016; Hidayat, 2016; Mulianah and Hidayat, 2016; Muliati, 2016; Sunubi, Dalle and Maghdalena, 2016; Anwar, 2016; Azis, Herdah and Jufri, 2016; Budiman, Musyarif and Firman, 2016; Ahdar, 2017; Ilham, 2017; Ipandang, 2017; Al-Amri and Haramain, 2017; Ulum and Haramain, 2017; Azis and Jufri, 2017; Khairul and Haramain, 2018; Muammar and Suhartina, 2018; Tanwir and Said, 2018)(Haramain, 2017; Ulum and Haramain, 2017)

Masyarakat dibentuk oleh komunikasi dan komunikasi itu sendiri. Komunikasi disini bukan merujuk pada makna klasik atau model "senderreceiver", "komunikasi” bukan tindakan tunggal tetapi selalu terdiri dari

\footnotetext{
${ }^{5}$ Daniel Goleman, Social intelligence (Jakarta: PT Gramedia Pustaka Utama 2007) h. 444

${ }^{6}$ Catur Saptaning Wilujeng dan Tatag Handaka, Komunikasi kesehatan (Malang: Ub Press 2017) h.104
} 
tiga hal, yaitu informasi, pesan dan pemahaman. System komunikasi adalah system tertutup yang lengkap, menciptakan komponen-komponen yangmembentuk dirinya melalui komunikasi itu sendiri. Dalam kaitan hal ini, system komunikasi adalah system autopoiesis yang memproduksi dan mereproduksi sesuatu yang berfungsi sebagai unit untuk system melalui system itu sendiri. Tentu, hal ini hanya dapat terjadi dalam sebuah lingkungan dan tergantung pada batasan-batasan aturan/hokum lingkungannya.

\subsubsection{Teori gaya kepemimpinan}

Paul Hersey dan Ken Blanchard telah mengembangkan sebuah model kepemimpinan yang memperoleh banyak pengikut setia di kalangan spesialis pengembangan manajemen, model ini yang disebut teori kepemimpinan situasional (Situational Leadership theory) telah diinkorporasikan ke dalam berbagai program pelatihan kepemimpinan di lebih dari 400 dari 500 perusahaan fortuner dan tiap tahunnya lebih dari satu juta manajer dan berbagai organisasi mempelajari elemen-elemen dasarnya. ${ }^{7}$ Kepemimpinan situasional adalah sebuah teori kemungkinan yang berfokus pada para pengikut. Kepemimpinan yang berhasil dicapai dengan cara memilih gaya kepemimpinan yang benar, yang menurut Hersey dan Blanchard bergantung pada tingkat kesiapan para pengikut.

Penekanan para pengikut dalam efektivitas kepemimpinan mencerminkan realitas bahwa para pengikutlah yang menerima atau menolak pemimpin tersebut. Terlepas dari apa yang dilakukan oleh pemimpin, efektivitas bergantung pada tindakan para pengikut. Ini merupakan salah satu dimensi penting yang lama diabaikan atau diremehkan di sebagian besar teori kepemimpinan. Istilah kesiapan, sebagaimana didefenisikan oleh Hersey dan Blanchard, merujuk pada tingkat sampai mana orang memiliki kemampuan dan kesediaan untuk menyelesaikan tugas tertentu.

${ }^{7}$ P. Robbins dan Timothy A. Judge, Perilaku organisasi (Jakarta: Salemba empat 2008) 


\section{REFERENCES}

Abdullah, B. (2016) 'KONSTITUSI PENDIDIKAN ISLAM DALAM MEMBANGUN MASYARAKAT MADANI', KURIOSITAS: Media Komunikasi Sosial Keagamaan, 9(2), pp. 79-86.

Ahdar, A. (2017) 'TINJAUAN KRITIS DAN MENYELURUH TERHADAP FUNDAMENTALISME DAN RADIKALISME ISLAM MASA KINI', KURIOSITAS: Media Komunikasi Sosial dan Keagamaan, 10(1), pp. 19-36.

Al-Amri, L. and Haramain, M. (2017) 'AKULTURASI ISLAM DALAM BUDAYA LOKAL', KURIOSITAS, 10(2), pp. 87-100.

Anwar, A. (2016) 'KONTRIBUSI KELUARGA TERHADAP PEMBENTUKAN KARAKTER ANAK (Studi Perspektif Modal Sosial di Kota Parepare)', KURIOSITAS, 9(1), pp. 57-65.

Azis, A. and Jufri, M. (2017) 'IMPLEMENTASI NILAI-NILAI AJARAN TAU LOTANG TERHADAP MASYARAKAT LOKAL WATTANG BACUKIKI KOTA PAREPARE', KURIOSITAS: Media Komunikasi Sosial dan Keagamaan, 10(2), pp. 2341.

Azis, S. A., Herdah, H. and Jufri, M. (2016) 'IMPLEMENTASI MODEL PEMBELAJARAN KOOPERATIF MAHASISWA PROGRAM STUDI BAHASA ARAB STAIN PAREPARE (Studi Pengembangan Pembelajaran Mata Kuliah Serumpun)', KURIOSITAS, 9(1), pp. 81-102.

Budiman, B., Musyarif, M. and Firman, F. (2016) 'IDEOLOGI BULETIN DAKWAH AL-ISLAM DALAM KAJIAN WACANA KRITIS', KURIOSITAS, 9(1), pp. 21-34.

Haramain, M. (2012) 'Pemikiran dan Gerakan Dakwah Tuan Guru M. Zainuddin Abdul Madjid di Lombok NTB’. Makassar: Universitas Islam Negeri Alauddin Makassar.

Haramain, M. (2016) 'al-Wasathiyyah wa Atsaruha fi al-da'wah al-Islamiyyah: Dirasah Lugawiyyah Manhajiyyah', Langkawi: Journal of The Association for Arabic and English, 2(1), pp. 83-100.

Haramain, M. (2017) 'DAKWAH DALAM ARUS GLOBALISASI MEDIA: PELUANG 
DAN TANTANGAN', KOMUNIDA: MEDIA KOMUNIKASI DAN DAKWAH, 7(1), pp. $60-73$.

Haramain, M. (2019) Prinsip-prinsip Komunikasi dalam al-Qur'an. Parepare: IAIN Parepare Nusantara Press.

Hidayat, W. (2016) 'PERSEPSI SISWA SMA KOTA PAREPARE TENTANG STAIN PAREPARE', KURIOSITAS: Media Komunikasi Sosial Keagamaan, 9(1), pp. 49-56.

Ilham, M. I. M. (2017) 'HERMENEUTIKA AL-QUR'AN', KURIOSITAS: Media Komunikasi Sosial dan Keagamaan, 10(2), pp. 101-119.

Ipandang, I. (2017) 'FILSAFAT AKHLAK DALAM KONTEKS PEMIKIRAN ETIKA MODERN DAN MISTISISME ISLAM SERTA KEMANUSIAAN', KURIOSITAS: Media Komunikasi Sosial dan Keagamaan, 10(1), pp. 1-18.

Juddah, A. B. (2015) 'ANALITIS SINTETIK TERHADAP STRATEGI PEMBELAJARAN ANDRAGOGI BERPERSPEKTIF KEMANDIRIAN DOSEN DALAM PEMBELAJARAN', Kuriositas: Media Komunikasi Sosial dan Keagamaan, $8(2)$, pp. $41-45$.

Khairul, K. and Haramain, M. (2018) 'Aplikasi Digital Risalah Ilmu Tajwid dalam Meningkatkan Kemampuan Baca Al Qur'an', KURIOSITAS: Media Komunikasi Sosial dan Keagamaan, 11(2), pp. 145-157.

Muammar, M. and Suhartina, S. (2018) 'Media Pembelajaran Berbasis Teknologi Informasi Dalam Meningkatkan Minat Belajar Akidah Akhlak', KURIOSITAS: Media Komunikasi Sosial dan Keagamaan, 11(2), pp. 176-188.

Mulianah, S. and Hidayat, W. (2016) 'PENGEMBANGAN TES BERBASIS KOMPUTER', KURIOSITAS: Media Komunikasi Sosial dan Keagamaan, 9(2), pp. 2743.

Muliati, M. (2016) 'PENGARUH PAHAM KEAGAMAAN TERHADAP ETOS KERJA PEDAGANG PASAR SENTRAL KABUPATEN PINRANG', KURIOSITAS: Media Komunikasi Sosial Keagamaan, 9(2), pp. 101-115.

Rahmawati, R., Wahidin, W. and Aris, A. (2015) 'MATERI FIQH IBADAH DAN 
IMPLEMENTASINYA BAGI MAHASISWA JURUSAN SYARIAH STAIN PAREPARE', KURIOSITAS: Media Komunikasi Sosial Keagamaan, 8(1), pp. 71-86.

Sunubi, A. H., Dalle, A. and Maghdalena, M. (2016) 'ENGLISH TEACHER INSTRUCTION IN GIVING MATERIAL BY USING CODE SWITCHING AND CODE MIXING IN SMU NEG. 2 PAREPARE', KURIOSITAS, 9(1), pp. 35-47.

Tanwir, T. and Said, H. (2018) 'Inovasi Pembelajaran Guru Pendidikan Agama Islam Berbasis Teknologi Informasi', KURIOSITAS: Media Komunikasi Sosial dan Keagamaan, 11(2), pp. 189-210.

Ulum, A. C. and Haramain, M. (2017) 'EKSISTENSI DAKWAH DALAM MERESPON PLURALISME', KOMUNIDA: MEDIA KOMUNIKASI DAN DAKWAH, 7(2), pp. 124138. 